\title{
EVIDENCE OF SPOTTED FEVER GROUP RICKETTSIAE IN STATE OF RIO DE JANEIRO, BRAZIL
}

\author{
Tatiana ROZENTAL (1), Maria Cristina BUSTAMANTE(2), Marinete AMORIM(3), Nicolau Maués SERRA-FREIRE(3) \& Elba Regina Sampaio de LEMOS(1)
}

\begin{abstract}
SUMMARY
Ticks were obtained from dogs from February to September of 1999 at weekly intervals, in the County of Piraí, State of Rio de Janeiro. Four hundred seventy four ixodids were taxonomically identified, 103 Amblyomma cajennense, seven Amblyomma ovale, 209 Rhipicephalus sanguineus, and 155 Amblyomma sp. An hemolymph test associated with Giemsa's stain revealed two specimens in 163 ticks tested ( $R$. sanguineus and Amblyomma sp), containing rickettsia-like organisms. Direct immunofluorescence verified the presence of spotted fever group rickettsia in one specimen of $R$. sanguineus. Considering the limited information on rickettsiosis in Brazil, principally in relation to the vectors involved in perpetuating it in foci, these preliminary results give us an idea on the importance of infection in ticks, allowing to expand our knowledge on this zoonosis.
\end{abstract}

KEYWORDS: Spotted fever; Ticks; Hemolymph test; Brazil

\section{INTRODUCTION}

Brazilian spotted fever (BSF), caused by Rickettsia rickettsii, is the most significant tick-borne disease in Brazil ${ }^{33,46}$.

The Cayenne tick ${ }^{9,17,47}$ (Amblyomma cajennense) is the most important vector of $R$. rickettsii, and humans are frequently bitten by larvae and nymphs of this arthropod.

Other groups of ixodids have also been implicated as transmissors and/ or reservoir of this zoonosis such as Amblyomma ovale, Amblyomma braziliensis, Amblyomma cooperi, Rhipicephalus sanguineus ${ }^{14,23,29,30,31,32,36,45}$.

Although most cases occurred in the Brazilian Southest region, these ticks are distributed throughout Brazil ${ }^{15,19,20,21,28,40,41,42,43}$. The absence of officialy reported cases of BSF in other regions may be due in part to the lack of confirmatory diagnostic tests and clinical suspicion.

This paper provides preliminary results on rickettsia-infected ticks in an area within the State of Rio de Janeiro, where sporadic cases of BSF has been confirmed since 1970'.

\section{MATERIALS AND METHODS}

The County of Piraí was chosen for this study based on three cases of BSF (two in 1977 and one in 1997) which have been confirmed in a neighbouring county, Barra do Piraí, and for the support offered by the County's Health Department to collaborate.

The County of Piraí is located in the Medio Paraíba Industrial Region in the State of Rio de Janeiro (22 37'44'S, 4353'59'W) that consists of five districts: Piraí, Monumento, Arrozal, Pinheiral, and Santanésia ${ }^{12,16}$. Ticks were collected in two neighborhoods, Cacaria and Serra do Matoso, in the District of Monumento (Fig. 1).

With the help of a veterinarian and two employees of the county's health office, 578 ticks were captured between February and September 1999. The arthropods were collected weekly from dogs and taxonomically identified $^{1,2,39}$ at the Department of Entomology, Laboratory of Ixodids, Oswaldo Cruz Institute. After entomologic analysis, the ticks were submitted to investigation for rickettsiae.

The ticks were desinfected with $10 \%$ formaldehyde solution, $70 \%$ alcohol and washed in sterile distilled water for five minutes.

For each live tick, two slides were prepared with the hemolymph, fixed in alcohol and acetone for 15 minutes ${ }^{5}$. The first slide was used for investigation of rickettsia-like organisms using Giemsa staining, and the second for the direct immunofluorescence test with $R$. rickettsii positive human serum and fluorescein.

\section{RESULTS}

Of the 578 ixodids collected from 129 dogs, 474 ticks were taxonomically identified (Table 1): 103 A. cajennense, seven A. ovale, 209 R. sanguineus, and 155 Amblyomma sp. (Table 2).

Hemolymph test and Giemsa staining: Of the 163 ticks submitted to hemolymph test, Giemsa staining was performed in only 153 ixodids (32.2\%), due to loss of material (slides). One nimph Amblyomma sp. displayed intracellular rickettsia-like particles in the nucleus and the 

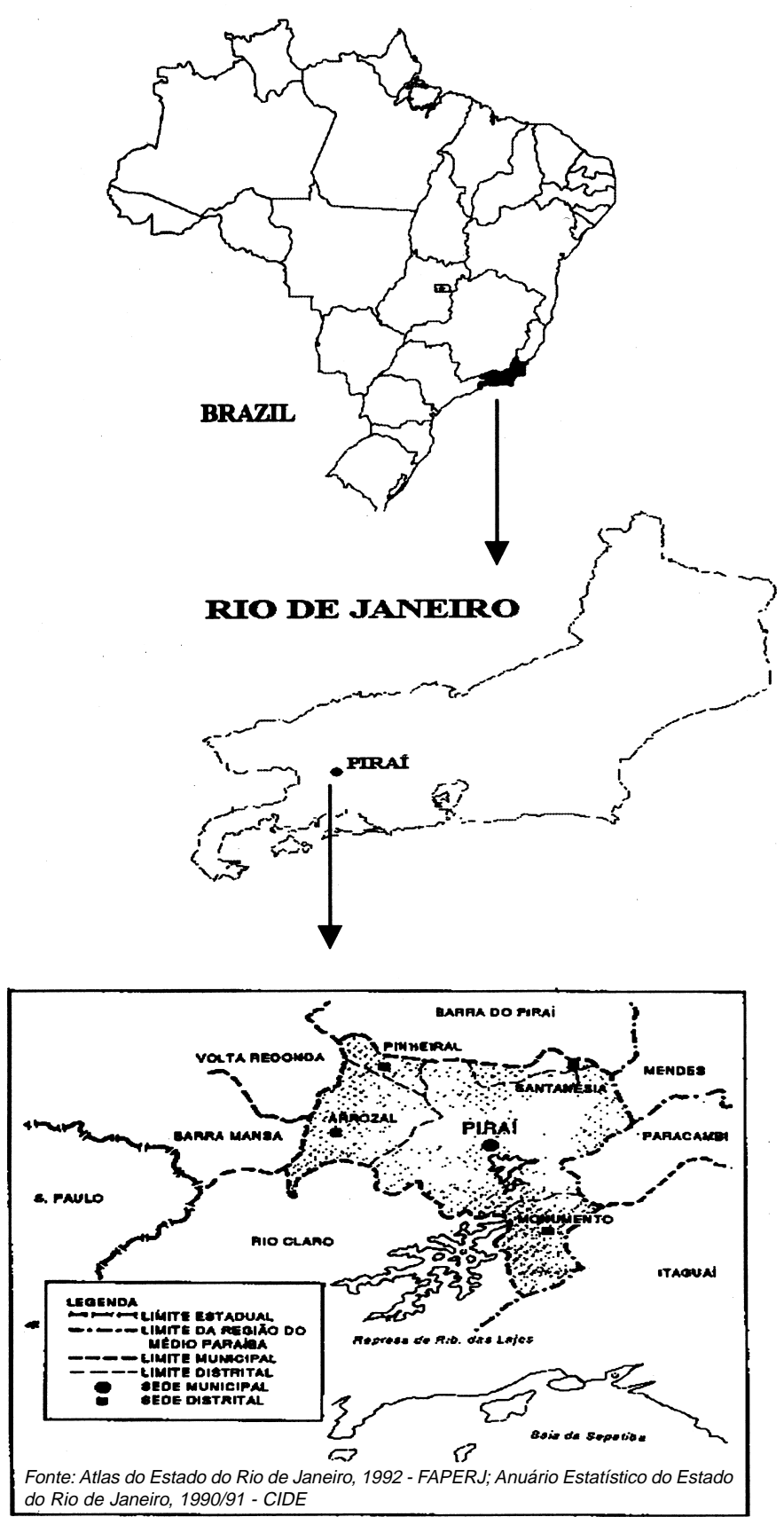

Fig. 1 - County of Piraí (Monumento District), Rio de Janeiro, Brazil.

cytoplasm of the hemocyte and one adult $R$. sanguineus only in the cytoplasm. The prevalence of infection found was $1.3 \%$.

\section{All positive exemplars were collected from Serra do Matoso.}

Hemolymph test and direct immunofluorescence: One hundred and sixty three ticks $(34.3 \%)$ were submitted to hemolymph test associated to direct immunofluorescence. The prevalence of infection to Spotted fever group rickettsiae was $0.6 \%$, detected in one nimph $R$.
Table 1

Number of ticks collected and identified

\begin{tabular}{lcc}
\hline Localities & $\begin{array}{c}\text { Total no. of ticks/ } \\
\text { Total no. of dogs }\end{array}$ & $\begin{array}{c}\text { Total no. of } \\
\text { ticks identified }(\%)\end{array}$ \\
\hline Cacaria & $122 / 33$ & $121(99.2 \%)$ \\
Serra do Matoso & $456 / 96$ & $353(77.4 \%)$ \\
TOTAL & $578 / 129$ & $474(81.8 \%)$ \\
\hline
\end{tabular}

Table 2

Number of ticks taxonomically identified collected from dogs

\begin{tabular}{llrrrr}
\hline Localities & Tick species & \multicolumn{4}{c}{ No. identified } \\
& & Larvae & Nymph & Adult & Total \\
\hline Cacaria & A. cajennense & - & - & 12 & 12 \\
& R. sanguineus & 5 & 7 & 90 & 102 \\
& Amblyomma $\mathrm{sp}$ & - & 7 & - & 7 \\
\multirow{5}{*}{ Serra do Matoso } & A. cajennense & - & 45 & 46 & 91 \\
& A. ovale & - & - & 7 & 7 \\
& Amblyomma sp & 12 & 136 & - & 148 \\
& R. sanguineus & 1 & 5 & 101 & 107 \\
\hline Total & & 18 & 200 & 256 & 474 \\
\hline
\end{tabular}

sanguineus specie. This positive exemplar was also collected from Serra do Matoso.

\section{DISCUSSION}

The Giemsa staining technique showed microorganisms with shape and size compatible with rickettsia. Although this technique is unspecific, unable to distinguish from other bacterias, the presence of infection in the nucleus of some hemocytes suggest, almost certainly, spotted fever group rickettsiae ${ }^{10}$. Another exemplar tested, only one tick presented rickettsia-like organisms, with rounding shape bacillus-like organisms that differed from the short, ovoid forms compatible with $R$. rickettsii. Although significant differences in the prevalence of the infection can be observed during the year, the results showed here are similar from other investigators, that perform studies in different regions in the World $25,26,27,37,38$.

The low prevalence $(0.6 \%)$ observed in the direct immunofluorescence assay may have been due to the small number of exemplars studied. In spite of this, a similar finding was observed by MAGNARELLI et al. $(1981)^{26}$ in Connecticut. Beside this, various studies on infection in ticks display wide variation, with prevalences ranging from $0.14 \%$ to $13.5 \%$,6,11,13,18,24,41,44 .

As this study was performed in a population of dogs, $R$. sanguineus (known as a vector for spotted fever caused by $R$. conorii in Europe) was the most abundant specie in the ixodid fauna studied that was positive by hemolymph test. They are also important because this tick may be implicated in maintaining spotted fever group rickettsiae in nature ${ }^{7,8,36}$. 
Several tick species may have an important role as vector and as reservoir in ecology of spotted fever group rickettsiae ${ }^{3,7,34}$. In Brazil, there are few studies about the presence of $R$. rickettsii or another spotted fever group rickettsiae although these arthropods are widely distributed throughout Brazilian territory.

Despite the small number of ticks collected and analyzed in this paper $(34.3 \%)$, the results indicate the existence of circulation of spotted fever group rickettsiae, pathogenic or not, in the region. The occurrence of confirmed cases of BSF in this locality of State of Rio de Janeiro in 1977 and 1997, ratify the affirmation above.

More informations will be obtained through molecular biology ${ }^{35}$ and isolation techniques ${ }^{22,35}$, with the purpose of confirmating the diagnosis of rickettsiosis in this region.

\section{RESUMO}

\section{Evidência de rickettsiae do grupo da febre maculosa no Estado do Rio de Janeiro, Brasil}

De fevereiro a setembro de 1999 , foram realizadas, semanalmente, coletas de carrapatos de cães no Município de Piraí/RJ. Quatrocentos e setenta e quatro ixodídeos foram taxonomicamente identificados, 103 Amblyomma cajennense, sete Amblyomma ovale, 209 Rhipicephalus sanguineus e 155 Amblyomma sp.

O teste de hemolinfa associado à coloração de Giemsa revelou que duas espécies de 163 carrapatos testados ( $R$. sanguineus e $A$. $s p$.) continham microrganismos com morfologia semelhante à rickettsia do grupo da febre maculosa.

No teste de imunofluorescência direta, mais específico, foi verificada a presença de rickettsia do grupo da febre maculosa em uma espécie de $R$. sanguineus.

Considerando que informações sobre rickettsioses no Brasil são limitadas, principalmente com relação aos vetores envolvidos na perpetuação da doença, estes resultados preliminares nos mostram a necessidade da realização deste tipo de estudo, permitindo, desta forma, aumentar nossos conhecimentos a respeito desta zoonose.

\section{ACKNOWLEDGEMENTS}

This research was supported by CNPq and FIOCRUZ.

\section{REFERENCES}

1. ARAGÃO, H. \& FONSECA, F. - Notas de Ixodologia. VIII. Lista e chave para os representantes da fauna ixodológica brasileira. Mem. Inst. Oswaldo Cruz, 59: 115130,1961 .

2. ARAGÃO, H. \& FONSECA, F. - Notas de Ixodologia. IX. O complexo Ovale do gênero Amblyomma. Mem. Inst. Oswaldo Cruz, 59: 131-148, 1961.

3. BELL, E.J.; KOHLS, G.M.; STOENER, H.G. \& LACKMAN, D.B. - Non pathogenic rickettsiae related to the spotted fever group isolated from ticks, Dermacentor variabilis and Dermacentor andersoni from Eastern Montana. J. Immunol., 90: 770-781, 1963.
4. BENACH, J.L.; WHITE, D.J.; BURGDORFER, W. et al. - Changing patterns in the incidence of Rocky Mountain spotted fever on Long Island (1971-1976). Amer. J. Epidem., 106: 380-387, 1977.

5. BURGDORFER, W. - Hemolymph test. A technique for detection of rickettsiae in ticks. Amer. J. trop. Med. Hyg., 19: 1010-1014, 1970.

6. BURGDORFER, W.; COONEY, J.C. \& THOMAS, L.A. - Zoonotic potential (Rocky Mountain spotted fever and tularemia) in the Tennessee Valley region. II. Prevalence of Rickettsia rickettsii and Francisella tularensis in mammals and ticks from Land Between the Laks. Amer. J. trop. Med. Hyg., 23: 109-117, 1974.

7. BURGDORFER, W.; SEXTON, D.J.; CERLOFF, R.K. et al. - Rhipicephalus sanguineus vector of a new spotted fever group rickettsia in the United States. Infect. Immun., 12: 205-210, 1975.

8. DELGADO, S. \& CARMENES, P. - Canine seroprevalence of Rickettsia conorii infection (Mediterranean spotted fever) in Castilla y Leon (northwest Spain). Europ. J. Epidem., 11: 597-600, 1995.

9. DIAS, E. \& MARTINS, A.V. - Spotted fever in Brazil. A summary. Amer. J. trop. Med., 19: $103-108,1939$.

10. ELISBERG, B.L. \& BOZEMAN, F.M. - The rickettsiae. In: LENNETE, E.H. \& SCHMIDT, N.J., ed. Diagnostic procedures in viral, rickettsial, and chlamydial infections. 5. ed. Washigton, American Public Health Association, 1979. p. 10611108.

11. Elliot, L.B.; FOURNIER, P.V. \& TELTON G.L. - Rickettsia in Texas. Ann. N. Y. Acad. Sci., 590: 221-226, 1990.

12. ESTUDOS PARA O PLANEJAMENTO MUNICIPAL - Piraí. Rio de Janeiro, Governadoria do Estado do Rio de Janeiro; Secplan; Fiderj, 1977. v. 37, p. 16-37.

13. FENG, W.C.; MURRAY, E.S.; BURGDORFER, W. et al. - Spotted fever group rickettsiae in Dermacentor variabilis from Cape Cod, Massachusetts. Amer. J. trop. Med. Hyg., 29: 691-694, 1980

14. GOMES, L.S. - Typho exanthemático de São Paulo. Vírus exanthemático, sob condições naturaes, isolado de carrapato (Amblyomma ovale Koch) capturado em cão de zona infectada. Brasil-méd., 52: 919-922, 1933.

15. GONÇALVES, A.J.R.; LOPES, P.F.A.; MELO, J.P.C. et al. - Rickettsioses: a propósito de quatro casos diagnosticados no Rio de Janeiro de febre maculosa brasileira. Folha méd. (Rio de J.), 82: 127-134, 1981.

16. GUIA SÓCIO-ECONÔMICO DOS MUNICÍPIOS DO ESTADO DO RJ. Rio de Janeiro, Gráfica JB, 1993. v. 2, p. 171-173.

17. HOOGSTRAAL, H. - Ticks in relation to human diseases caused by Rickettsia species. Ann. Rev. Ent., 12: 377-420, 1967.

18. LANE, R.S.; EMMONS, R.W.; DONDERO, D.V. \& NELSON, B.C. - Ecology of tickborne agents in California. I. Spotted fever group rickettsiae. Amer. J. trop. Med. Hyg., 30: 239-252, 1981

19. LEMOS, E.R.S. - Aspectos epidemiológicos da riquetsiose do grupo da febre maculosa em uma área endêmica do estado de Minas Gerais, Brasil. Rio de Janeiro, 1991. (Dissertação de Mestrado - Instituto Oswaldo Cruz, da Fundação Oswaldo Cruz).

20. LEMOS, E.R.S. - Febre maculosa brasileira em uma área endêmica no município de Pedreira, São Paulo, Brasil. Rio de Janeiro, 1996. (Dissertação de Doutorado Instituto Oswaldo Cruz, da Fundação Oswaldo Cruz).

21. LEMOS, E.R.S. - Rickettsioses. Arq. bras. Med., 2000 (in press).

22. LEMOS, E.R.S.; MELLES, H.H.B.; COLOMBO, S. et al.- Primary isolation of spotted fever group rickettsiae from Amblyomma cooperi collected from Hydrochaeris hydrochaeris in Brazil. Mem. Inst. Oswaldo Cruz, 91: 273-275, 1996. 
23. MAGALHÃES, O. - Contribuição ao conhecimento das doenças do grupo do tifo exantemático. Rio de Janeiro, Imprensa Nacional, 1952. (Monografias do Instituto. Oswaldo Cruz, № 6 ).

24. MAGNARELLI, L.A.; ANDERSON, J.F.; BURGDORFER, W.; PHILIP, R.N. \& CHAPPELL, W.A. - Spotted fever group rickettsiae in immature and adult ticks (Acari - Ixodidae) from a focus of Rocky Mountain spotted fever in Connecticut. Canad. J. Microbiol., 31: 1131-1135, 1985.

25. MAGNARELLI, L.A.; ANDERSON, J.F.; PHILIP, R.N. \& BURGDORFER, W. Antibodies to spotted fever-group rickettsiae in dogs and prevalence of infected ticks in southern Connecticut. Amer. J. vet. Res., 43: 656-659, 1982.

26. MAGNARELLI, L.A.; ANDERSON, J.F.; PHILIP, R.N.; BURGDORFER, W. \& CASPER, E. A. - Endemicity of spotted fever-group rickettsiae in Connecticut. Amer. J. trop. Med. Hyg., 30: 715-721, 1981

27. MAGNARELLI, L.A.; ANDERSON, J.F.; PHILIP, R.N.; BURGDORFER, W. \& CHAPPEL, L. - Rickettsiae-infected ticks (Acari-Ixodidae) and seropositive mammals at a focus for Rocky Mountain spotted fever in Connecticut, United States. J. med. Ent., 20: 151-156, 1983.

28. MELLES, H.H.B.; COLOMBO, S. \& SILVA, M.V. - Febre maculosa: isolamento de rickettsia em amostra de biópsia de pele. Rev. Inst. Med. trop. S. Paulo, 34: 37-41, 1992.

29. MONTEIRO, J.L. \& FONSECA, F. - Typho exanthemático de São Paulo. XI. Novas experiências sobre a transmissão experimental por carrapatos (Boophilus microplus e Amblyomma cajennense). Mem. Inst. Butantan, 7: 35-40, 1932.

30. MONTEIRO, J.L.; FONSECA, F. \& PRADO, A. - Pesquisas epidemiológicas sobre o typho exanthemático de São Paulo. Possibilidade da transmissão experimental do vírus por Ixodidae. Mem. Inst. Butantan, 6: 139-173, 1931.

31. MOREIRA, J.A. \& MAGALHÃES, O. - Typho exanthemático em Minas Geraes (4 comunicação). Brasil-méd., 50: 881-882, 1936.

32. PASCALE, H. - Rickettsiosis em São Paulo. Contribuição ao estudo da epidemiologia da febre maculosa e do tifo murino. In: INTER AMERICAN CONGRESS OF MEDICINE, 1., Rio de Janeiro, 1946. p. 5-37.

33. PEREIRA, H.G. \& TRAVASSOS, J. - Estudo comparativo das rickettsias da febre maculosa das Montanhas Rochosas e do tifo de São Paulo pela reação de fixação de complemento. Hospital (Rio de J.), 40: 123-129, 1951.

34. PHILIP, R.N. \& CASPER, E.A. - Serotypes of spotted fever group rickettsiae isolated from Dermacentor andersoni (styles) ticks in Western Montana. Amer. J. trop. Med. Hyg., 30: 230-238, 1981.
35. RADULOVIC, S.; FENG, H.-M.; CROCQUET-VALDES, P. et al. - Antigen-capture enzyme immunoassay: a comparison with other methods for the detection of spotted fever group rickettsiae in ticks. Amer. J. trop. Med. Hyg., 50: 359-364, 1994.

36. REGENDANZ, P. \& MUNIZ, J. - Pesquisas sobre a transmissão do typho exanthemático de São Paulo por ixodídeos. Brasil méd., 3: 45-48, 1936.

37. REHÁCEK, J.; VOSTA, J.; TARASEVIC, I.V. et al. - Rickettsioses studies. 3. Natural foci of rickettsioses in south Bohemia. Bull. Wld. HIth. Org., 55: 455-461, 1977.

38. REHACÉK, J.; ZUPANCICOVÁ, M.; ÁC, P. et al. - Rickettsioses studies. 2. Natural foci of rickettsioses in east Slovakia. Bull. Wld. Hlth. Org., 53: 31-38, 1976.

39. ROHR, C. - Estudos sobre ixodidas do Brasil. Rio de Janeiro, Trabalho do Instituto Oswaldo Cruz, 1909.

40. SAMPAIO, G.C.; FERREIRA, R.P.; PATELLI, M. et al. - Vasculite com gangrena dos artelhos em um paciente com rickettsiose. Rev. bras. Med., 45: 277-279, 1988.

41. SEXTON, D.J.; BURGDORFER, W.; THOMAS, L. \& NORMENT, B.R. - Rocky Mountain spotted fever in Mississippi: survey for spotted fever antibodies in dogs and for spotted fever group rickettsiae in dog ticks. Amer. J. Epidem., 103: 192 197, 1976.

42. SEXTON, D.J.; MUNIZ, M.; COREY, G.R. et al. - Brazilian spotted fever in Espírito Santo, Brazil: description of a focus of infection in a new endemic region. Amer. J. trop. Med. Hyg., 49: 222-226, 1993.

43. SOUZA, M.A.A.; PAULA, A.B.; PRIMO, J.D.A. et al. - Febre maculosa brasileira em Virginópolis, Minas Gerais. In: CONGRESSO BRASILEIRO DE INFECTOLOGIA 4., Salvador, 1991. Anais. p. 68.

44. TAYLOR, A.C.; HII, J.; KELLY, D.J.; DAVIS, D.R. \& LEWIS, G.E. - A serological survey of scrub, tick, and endemic typhus in Sabah, East Malaysia, South Asia. South Asian J. trop. Med. publ. Hith., 17: 613-619, 1986.

45. TRAVASSOS, J. - Studies on Rickettsial diseases in Brazil. In: INTERNATIONAL CONGRESS ON TROPICAL MEDICINE AND MALARIA, 4., Washington, 1948. p. $414-425$.

46. TRAVASSOS, J. \& DIAS, E. - Febre maculosa. Identidade imunológica dos vírus de Minas Gerais, São Paulo e das Montanhas Rochosas. Mem. Inst. Oswaldo Cruz, 34: 149-179, 1939.

47. TRAVASSOS, J. \& VALLEJO-FREIRE, A. - Criação artificial de Amblyomma cajennense para o preparo da vacina contra a febre maculosa. Mem. Inst. Butantan, 18: 147235, 1944-1945.

Received: 10 January 2002

Accepted: 30 April 2002 